J. Perinat. Med. 14 (1986) 27

\title{
Temperature regulation in healthy and resuscitated newborns im- mediately after birth
}

\author{
Christian Schubring
}

Department of Obstetrics and Gynecology, Evangelisches Krankenhaus, Giessen, Fed. Rep. Germany

\section{Introduction}

Immediately after birth, the newborn is able to react to cold stress by an increase in thermogenesis measured via his uptake of oxygen $\left(=\mathrm{O}_{2}-\right.$ consumption, $\mathrm{VO}_{2}$ ) [5]. This reaction essentially results from the activation of non-shivering thermogenesis (NST). The brown adipose tissue (BAT) is supposed to be the site of NST. In the newborn, the thermoregulatory system reacts in a much more sensitive way than in the adult, and it is a sensitive indicator of any disturbances of energy metabolism. This paper has been written in an attempt to study, by continuous measurement of both $\dot{\mathrm{VO}}_{2}$ and rectal temperature (RT) immediately after birth if thermoregulatory processes are different in healthy and resuscitated neonates.

\section{Method}

The continuous measurement of $\mathrm{VO}_{2}$ and RT was carried out within the first 140 minutes following delivery and during 30 minutes the following four days of life. The method by which $\dot{\mathrm{VO}}_{2}$ and $\mathrm{RT}$ were measured, has already been described $[6,11]$. In 31 mature newborns, both blood gas analyses and Apgar scores were within the normal range. Thirteen mature neonates had to be temporarily supplied with oxygen after birth because they showed pathological blood gas values together with Apgar scores below 7 .

\section{Results}

In the healthy newborns, the $\mathrm{VO}_{2}$ used to continuously decrease from the beginning of examination until the 105th minute. Subsequently, the $\mathrm{VO}_{2}$ value ranged between 4.60 and 4.85 $\mathrm{ml} / \mathrm{kg} \cdot \min$ (standard metabolic rate). The $\mathrm{VO}_{2}$ measured between the second and the fifth day of life differed but insignificantly from the $\mathrm{VO}_{2}$ determined within the 120th to 140th minute after birth. The resuscitated newborns had an increasing $\mathrm{VO}_{2}$ until the 30th minute, when a drop was observed. Until the 130th postnatal minute, a clear distinction could be made between the group mean values of $\mathrm{VO}_{2}$ of healthy and resuscitated neonate respectively. Subsequently, there was an overlap in the range of measuring error which continued over the following four days after birth (figures 1 and 2).

The graphic representation of the range of measurement error for RT showed that a clear distinction between the curves of group mean values of healthy and resuscitated children could not be made at all times. An overlap was observed both at the beginning of measurement at 15 minutes and again from the 75th minute onwards (figure 3). In the healthy children examined there was a negative correlation, $\mathrm{r}=$ -3.85 , between $\mathrm{RT}(\mathrm{y})$ and $\mathrm{V}_{2}(\mathrm{x})$. The equation of the common regression straight line reads as follows: $y=37.59-0.16 \mathrm{ml} \mathrm{O}_{2}$. The individual straight line regression curves had 
$\mathrm{ml} / \mathrm{kg} \cdot \min \mathrm{VO}_{2}$

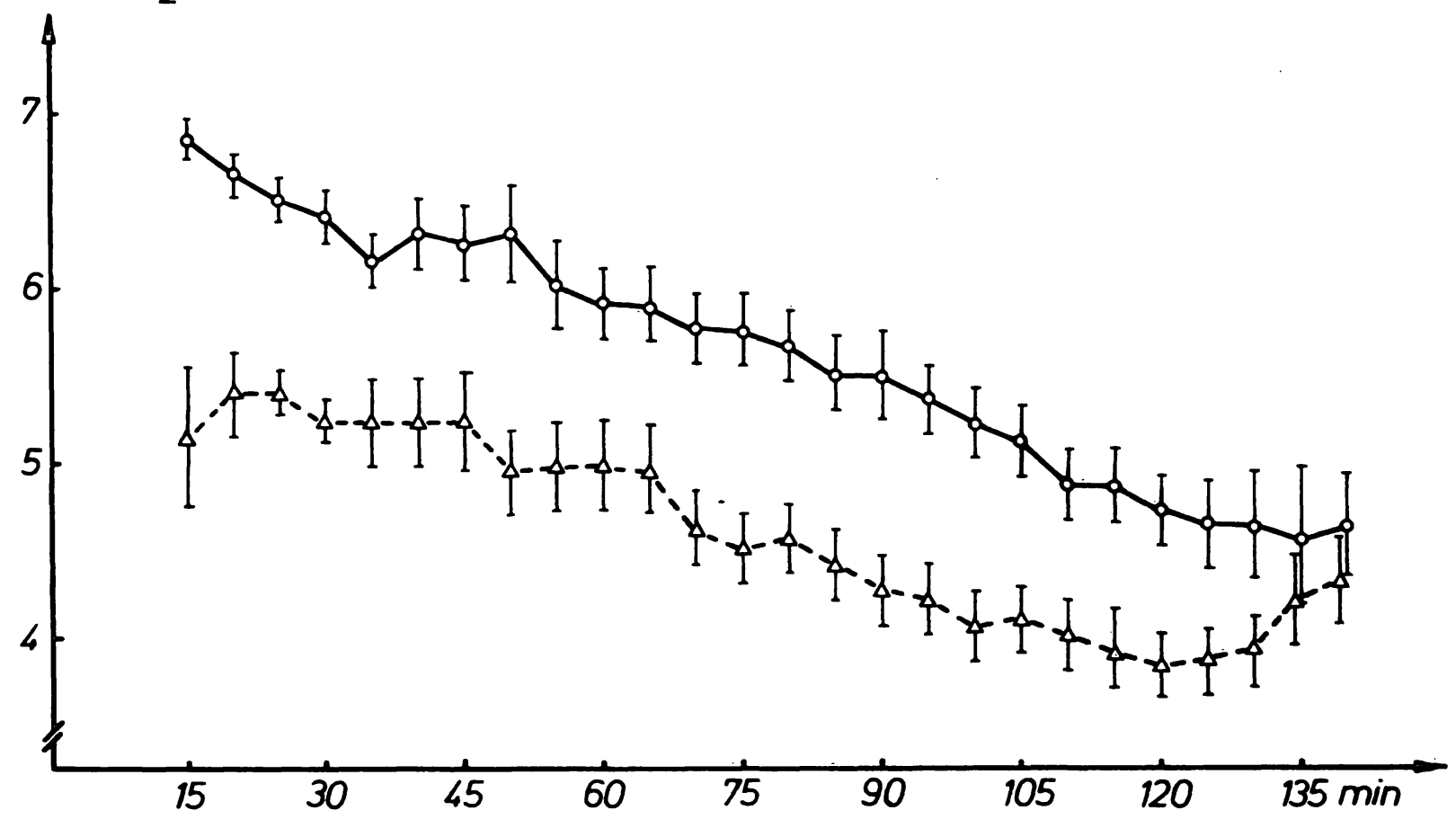

Figure 1. $\dot{\mathrm{V}} \mathrm{O}_{2}$ in 31 healthy $(\mathrm{o})$ and 13 resuscitated $(\Delta)$ newborns during the first 140 postnatal minutes; $\overline{\mathrm{x}} \pm \mathrm{s}_{\overline{\mathrm{x}}}$

$\mathrm{ml} / \mathrm{kg} \cdot \min \dot{\mathrm{VO}}_{2}$

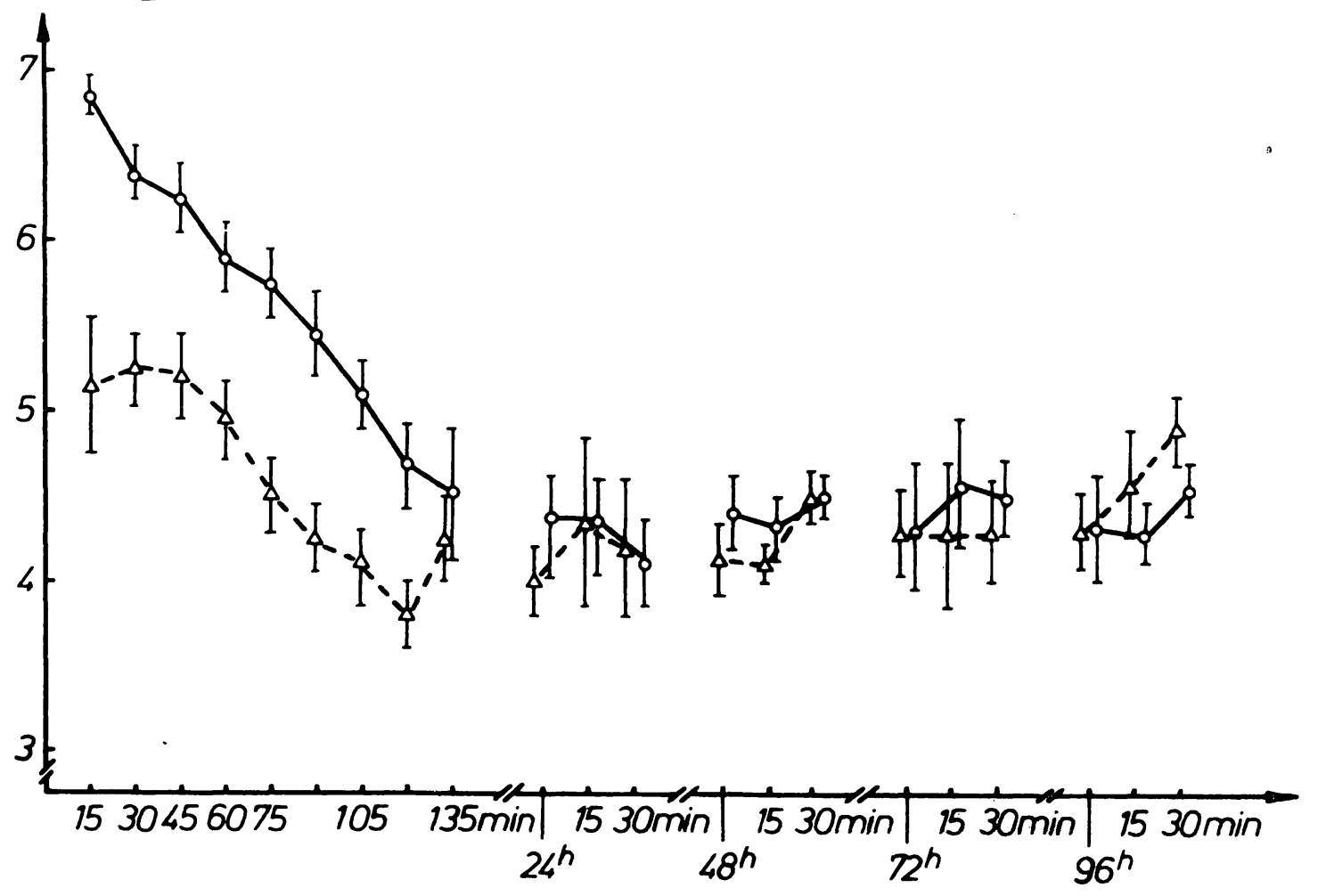

Figure 2. $\dot{\mathrm{VO}}_{2}$ in 31 healthy $(0)$ and 13 resuscitated $(\Delta)$ newborns during the first five days; $\overline{\mathrm{x}} \pm \mathrm{s}_{\overline{\mathrm{x}}}$. 


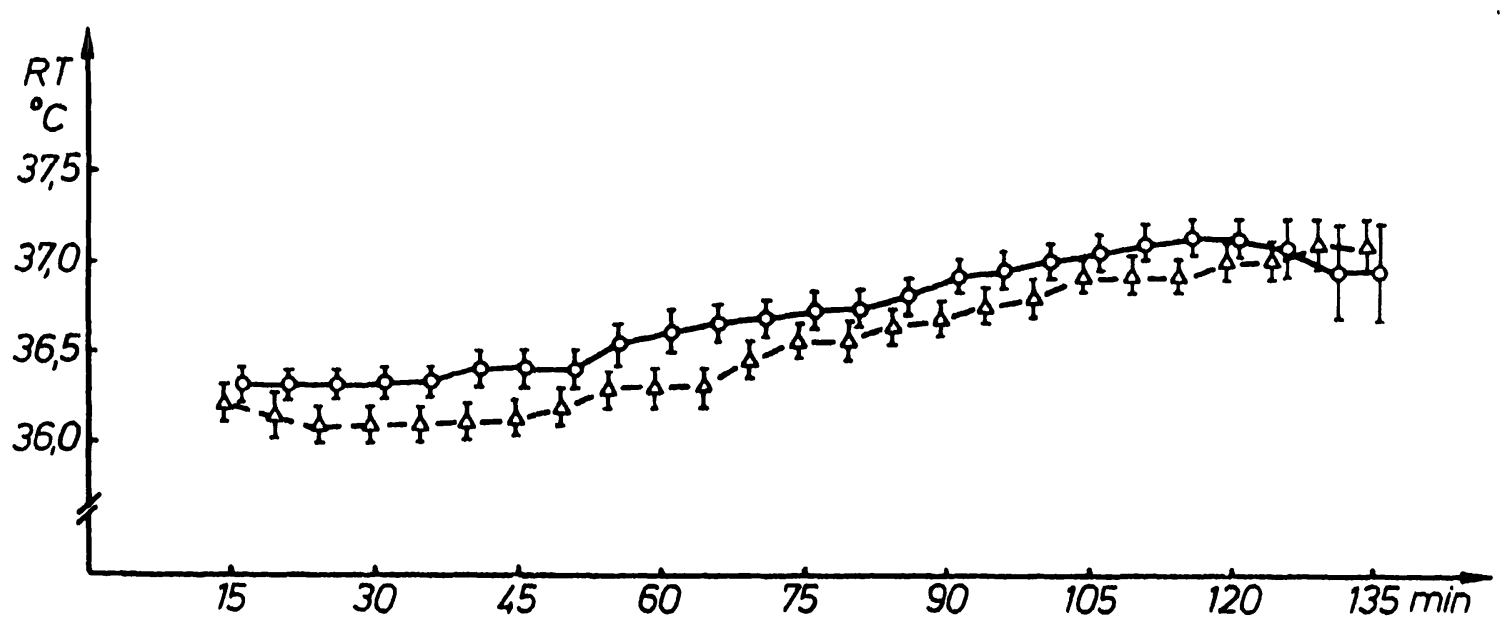

Figure 3. RT in 31 healthy (o) and 13 resuscitated $(\Delta)$ newborns; $\bar{x} \pm s x$.

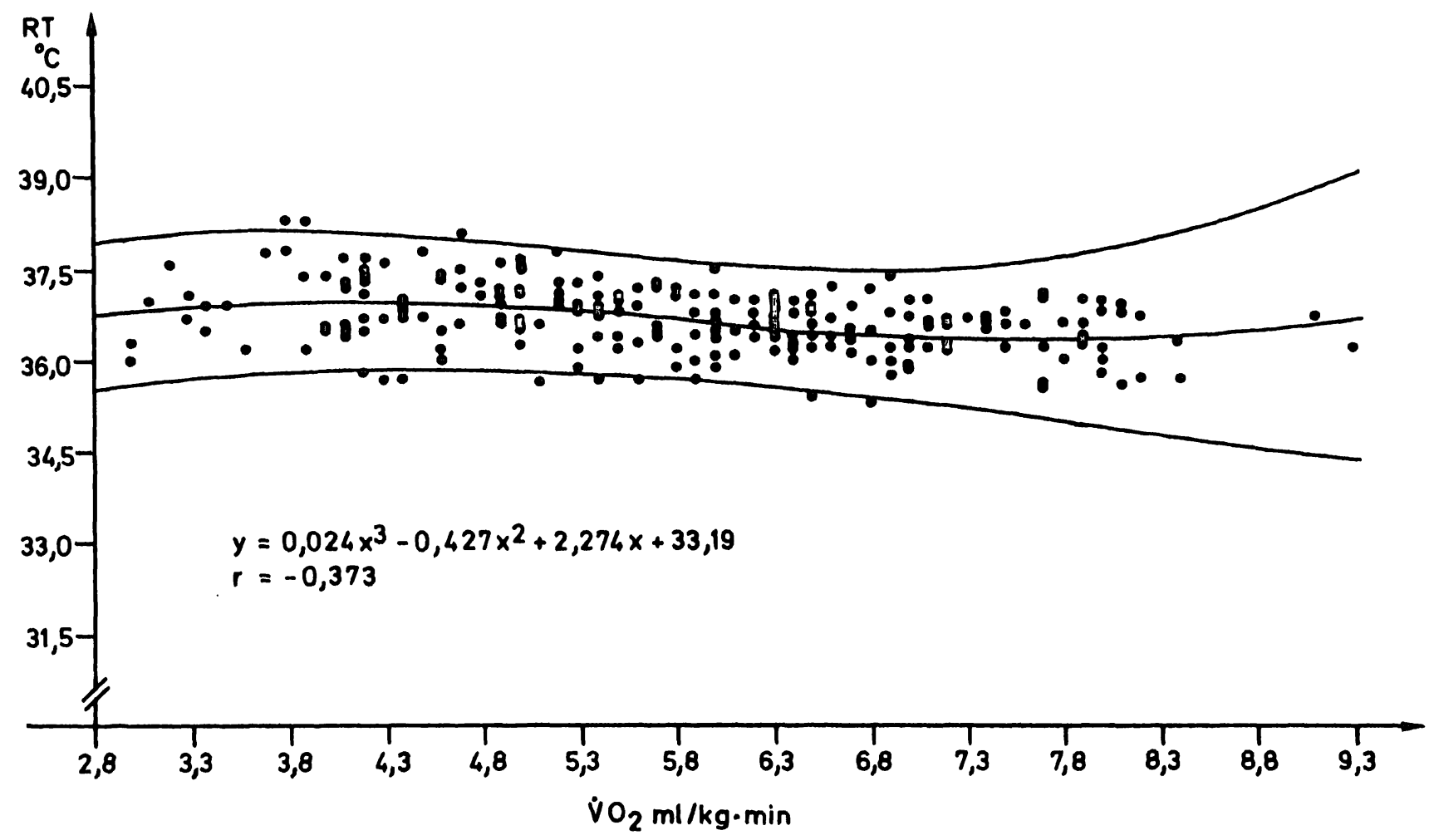

Figure 4. Regression $\dot{\mathrm{VO}} 2-\mathrm{RT}$ in 31 healthy newborns during the first 135 postnatal minutes.

different gradients at the individual times of measurement. A cubic function was calculated as the optimum significant curve adaptation (figure 4). In the presence of a low $\dot{\mathrm{VO}}_{2}$ round about $4.6 \mathrm{ml} / \mathrm{kg} \cdot \min , \mathrm{RT}$ of approx. $37^{\circ} \mathrm{C}$ was measured. These conditions were observed towards the end of the study. At the beginning of measurement, an $\dot{\mathrm{VO}}_{2}$ of approx. $6.8 \mathrm{ml} / \mathrm{kg}$
- min correspondend to RT of approx. $36.3^{\circ} \mathrm{C}$. A high $\dot{\mathrm{VO}}_{2}$ in the presence of a low RT used to indicate that thermoregulation was intact. The statistical check of the relationship between $\mathrm{VO}_{2}$ and RT in the resuscitated newborns gave as a results a negative correlation with the common equation of regression, $y=37.70-0.25$ $\mathrm{ml} \mathrm{O}_{2}$, and the coefficient of correlation, $\mathrm{r}=$ 


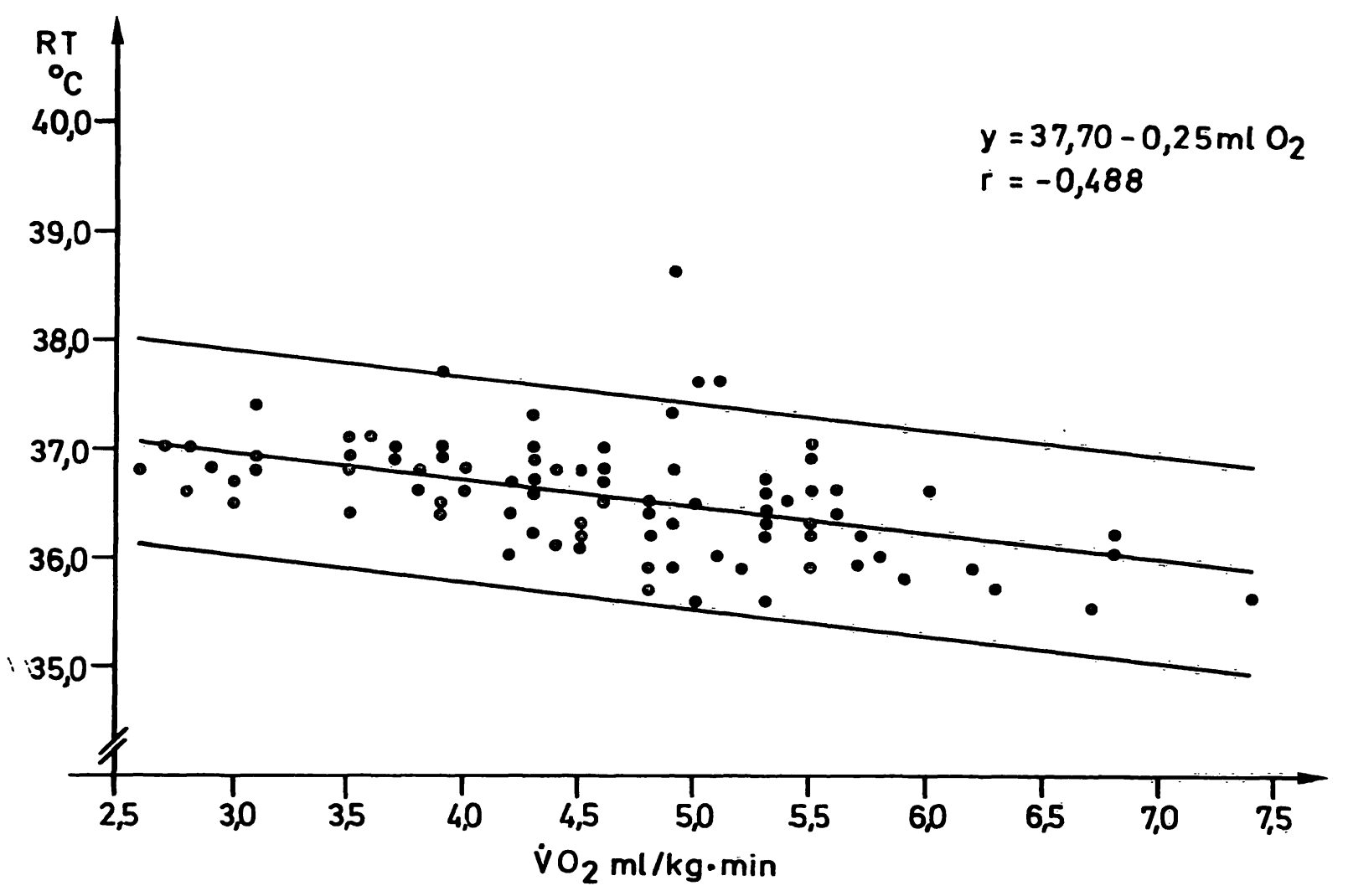

Figure 5. Regression $\mathrm{V}_{2}-\mathrm{RT}$ in 13 resuscitated newborns during the first 135 postnatal minutes.

-0.488 . The individual straight regression lines had a different gradient at the individual times of measurement. The linear function presented the optimum adaptation to the given conditions (figure 5).

\section{Discussion}

Both in previous studies [10] and in the present one (figure 1), we have been able to demonstrate that immediately after birth the oxygen uptake of healthy newborns initially is high, whereupon it will decrease over the observation period. According to the literature $[3,4]$ the course may be interpreted as follows: a thermoregulatory increase in $\mathrm{VO}_{2}$ has set in as a result of the cold stress during birth (RT of approx. $36.2^{\circ} \mathrm{C}$ ). In the course of the investigation a rise in temperature will take place (RT of approx. $37.0^{\circ} \mathrm{C}$ ), and the thermoregulatory process will fade away. The $\mathrm{VO}_{2}$ therewith approaches the minimum value (standard metabolic rate). The $\mathrm{VO}_{2}$ measured from the 110th minute on $(4.85$
$-4.60 \mathrm{ml} / \mathrm{kg} \cdot \mathrm{min}$ ) is within the range of the value detailed in literature as to be applicable to healthy neonate $[1,5]$. Owing to the manipulation associated with resuscitation the resuscitated newborns were additionally cooled in a thorough way after birth. Furthermore, they were temporarily exposed to oxygen deficiency, which had to be controlled by the resuscitative measures. Both hypoxia and a prolonged cold exposure resulted in a decreased $\dot{\mathrm{VO}}_{2}$. If one assumes that cold exposure will lead to an increase in $\dot{\mathrm{VO}}_{2}$, the question arises as to how this thermogenetic process - NST - may be impaired by hypoxia? This reduction of $\mathrm{VO}_{2}$ might be due to an insufficient perfusion of the BAT as well as to a redistribution of the circulating blood volume. Since the activity of the BAT is dependent on oxygen supply, hypoxia might be regarded as the limiting factor. This assumption has been confirmed by animal experiments [2]. Hence, shifts of the circulating fetal blood volume will occur under hypoxia so that the oxygen supply of the vital organs will 
be guaranteed [8]. It may be assumed that the severely impaired blood flow to peripheral tissues will lead to an impairment of the aerobic metabolism in the BAT with its thermoregulatory activity, and thus will results in a low $\mathrm{VO}_{2}$. Circulatory disturbances of the skin will affect the cutaneous thermoreceptors which are responsible for the induction of the regulatory increase in thermogenesis [3]. The deficient thermoregulatory increase in $\mathrm{VO}_{2}$ also may result from central disturbances associated with a reduction of the threshold temperature required for the induction of metabolic defence reactions. It is known that hypercapnia may provoke such a reduction of the threshold temperature [9].

In the presence of an unchanging metabolic rate, the RT of newborns will fall more with a lower environmental temperature [7]. In the presence of equal environmental temperatures, the rectal temperatures of the healthy children differed from those of the resuscitated neonates. This is clear evidence of the fact that thermoregulatory processes may be impaired by difficult childbirth [3]. If healthy children are compared to resuscitated ones with regard to their relationship between $\mathrm{VO}_{2}$ and RT (figures 4 and 5), a striking inhibition of thermoregulation will be observed in the resuscitated newborns, particularly at the beginning of measurement (healthy newborns: approx. $6.8 \mathrm{ml} / \mathrm{kg} \cdot \mathrm{min}$; resuscitated newborns: approx. $5.2 \mathrm{ml} / \mathrm{kg} \cdot \mathrm{min}$ ). Towards the end of the study, the VंO and RT values of either group were more and more approximating to each other. It was noticeable that the $\dot{\mathrm{V}}_{2}$ exceeded $7.0 \mathrm{ml} /$ $\mathrm{kg} \cdot \mathrm{min}$ in one child. It was within this very range that the healthy children had exhibited an intact thermoregulation by their high $\dot{\mathrm{VO}}_{2}$.

The adaptation of the newborn to extrauterine life may be continuously monitored by measurement of the $\dot{\mathrm{VO}}_{2}$, a simple technique and consequently an easily applicable one in clinic practice. Deviations from the minimum $\mathrm{V}_{2}$ during the adaptatic phase immediately after birth will indicate any metabolic stress in a rapid and sensitive way.

\section{Summary}

Oxygen consumption $\left(\mathrm{V}_{2}\right)$ is a sensitive and reliable indicator of any disturbances of thermoregulatory adaptation in the newborn. This study has been carried out in a attempt to find out, if there is any difference between the thermoregulatory processes of healthy and resuscitated neonates. To this end, both $\dot{\mathrm{VO}}_{2}$ and rectal temperature (RT) were continuously measured in 31 healthy and 13 resuscitated neonates respectively, within the first 140 postnatal minutes and during 30 minutes from the second until the fifth day of their lives.

In the healthy neonates, the $\mathrm{VO}_{2}$ used to decrease over the study period (figure 1). The high initial $\mathrm{VO}_{2}$ observed postnatally is due to mechanisms of thermoregulation beginning immediately after delivery as soon as the newborn child is exposed to chilly environmental temperatures. The brown adipose tissue (BAT) is supposed to be the essential site of non-shivering thermogenesis (NST). The thermogenetic function of this tissue may be shown by local measuring of temperature.

In the resuscitated neonates, $\mathrm{VO}_{2}$ was lower than in the healthy children (figure 1). Hypoxia results in an

ineffective capillary blood supply of the BAT owing to a redistribution of circulating blood volume, thus leading to a disturbance of thermoregulation. Since the activity of the BAT is dependent on oxygen supply hypoxia might be regarded as the limiting factor.

In the presence of an isothermal environment, the RT measured in the healthy children differed from those determined in the resuscitated neonates (figure 2). This clearly shows that thermoregulatory processes may be impaired by a difficult birth.

By means of the present investigation, the minimum $\mathrm{VO}_{2}$ (standard metabolic rate) in the first adaptation period following birth has now been established, and any deviations may be evaluated as to their diagnostic relevance. Thus, continuous mcasuring of the $\dot{\mathrm{VO}}_{2}$ may be of effective use to the control of the adaptation of the newborn to the new environment he is exposed to after birth. The measuring method is non-invasivc; its clinical application is simple and completely safe for the newborn.

Keywords: Neonatal adaptation, newborn, oxygen consumption $\left(\dot{\mathrm{V}} \mathrm{O}_{2}\right)$, rectal temperature (RT), surveillance, thermoregulation. 
Thermoregulation bei gesunden und reanimierten Neugeborenen unmittelbar nach der Geburt

Der Sauerstoffverbrauch $\left(\mathrm{V}_{2}\right)$ zeigt Störungen der thermoregulatorischen Adaptation des Neugeborenen empfindlich und zuverlässig an. Hier soll untersucht werden, ob sich thermoregulatorische Stellvorgänge bei gesunden und reanimierten Neugeborenen unterscheiden. Aus diesem Grund wurden bei 31 gesunden und 13 reanimierten Neugeborenen in den ersten 140 Minuten nach der Geburt und in den ersten 4 Lebenstagen jeweils 30 Minuten kontinuierlich der $\dot{\mathrm{VO}}_{2}$ und die Rektaltemperatur (RT) gemessen.

Bei den gesunden Neugeborenen fiel der $\mathrm{V}_{2}$ über den Untersuchungszeitraum ab (Abb. 1). Für den anfänglich hohen $\mathrm{VO}_{2}$ nach der Geburt sind Thermoregulationsmechanismen verantwortlich, die sofort nach der Geburt einsetzen, wenn das Neugeborene in eine kühle Umgebung kommt. Als wesentlicher Ort der zitterfreien Thermogenese (NST) gilt das braune Fettgewebe (BAT). Die thermogenetische Funktion dieses Gewebes läßt sich durch lokale Temperaturmessung veranschaulichen.

Beim reanimierten Neugeborenen war der $\dot{\mathrm{V}} \mathrm{O}_{2}$ niedriger als bei den gesunden Kindern (Abb. 1). Unter Hypoxie kommt es zu einer ineffektiven Kapillardurchblutung des BAT durch eine Neuverteilung des zirkulierenden Blutvolumens und dadurch zu einer Störung der Thermoregulation. $\mathrm{Da}$ die Aktivität des BAT abhängig ist von der $\mathrm{O}_{2}$-Zufuhr, könnte man in der Hypoxie den limitierenden Faktor sehen. Bei gleichen Umgebungstemperaturen unterschied sich die RT bei den untersuchten gesunden und reanimierten Kindern (Abb. 2). Dies zeigt deutlich, daß durch eine schwierige Geburt thermoregulatorische Vorgänge gestört werden können. Zwischen $\dot{\mathrm{VO}}_{2}$ und $\mathrm{RT}$ fand sich eine negative Korrelation bei gesunden und reanimierten Neugeborenen (Abb. 3 u. 4).

Durch die vorliegenden Untersuchungen liegt jetzt der minimale $\mathrm{VO}_{2}$ (standard metabolic rate) in der ersten Adaptationsphase nach der Geburt fest, und Abweichungen können in ihrer diagnostischen Aussagekraft beurteilt werden. So kann die kontinuierliche Messung des $\dot{\mathrm{VO}}_{2}$ gut zur Überwachung der Adaptation des Neugeborenen an die neue Umwelt nach der Geburt eingesetzt werden. Die Meßmethode ist unblutig, klinisch einfach anzuwenden und für das Neugeborene vollkommen ungefährlich.

Schlüsselwörter: Neonatale Adaptation, Neugeborenes, Rektaltemperatur, Sauerstoffverbrauch, Thermoregulation, Überwachung.

\section{Résumé}

\begin{abstract}
Régulation thermique immédiatement après la naissance chez les nouveaux-nés en bonne santé et réanimés $\mathrm{La}$ consommation d'oxygène $\left(\mathrm{V}_{2}\right)$ est un indicateur sensible et fiable de toute perturbation de l'adaptation thermorégulatoire du nouveau-né. On a effectué cette étude dans le but de trouver s'il y a une différence entre le processus de thermorégulation chez le nouveau-né en bonne santé et chez les nouveaux-nés réanimés. Pour cela on a mesuré en continu la $\mathrm{VO}_{2}$ et la température rectal (RT) chez 31 nouveaux-nés en bonne santé et chez 13 réanimés, au cours des 140 premières minutes postnatales et pendant des periodes de 30 minutes à partir $\mathrm{du}$ second jour jusqu'au cinquième jour de vie.

Chez les nouveaux-nés en bonne santé, la $\mathrm{V}_{2}$ diminue au cours de la période étudiée (figure 1). $\mathrm{La} \mathrm{V}_{2}$ initial élevée que l'on observe en postnatal est secondaire aux mécanismes de thermorégulation qui commencent immédiatement après l'accouchement, dés que le nouveauné est exposé aux températures fraîches de l'environnement. Le tissu adipeux brun (BAT) est le site essentiel de la thermogénèse sans frissons (NST). On peut montrer la fonction de thermogène de ce tissu par la mesure locale de la température.
\end{abstract}

Chez les nouveaux-nés réanimés la $\mathrm{V}_{2}$ est plus basse que chez les enfants en bonne santé (figure 1). L'hypoxie aboutit à une suppléance capillaire sanguine ineffective $\mathrm{du}$ BAT due à une redistribution du volume sanguin circulatoire, ce qui conduit à un trouble de la thermorégulation. L'hypoxie peut être considérée comme le facteur limitant puisque l'activité du BAT dépend de son arrivage en oxygène.

Dans un environnement isothermique, la RT mesurée chez les nouveaux-nés en bonne santé diffère de celle qui est mesurée chez les nouveaux-nés réanimés (figure 2). Cela montre clairement que les processus de thermorégulation peuvent être diminués par une naissance difficile.

$\mathrm{Au}$ moyen de ces investigations, la $\dot{\mathrm{VO}}_{2}$ minimale (taux métabolique standard) au cours de la période de la première adaptation qui suit la naissance a été établie, et on peut évaluer les variations ainsi que les diagnostics en cause. Ainsi, la mesure continue de la $\mathrm{VO}_{2}$ peut être utilisée avec efficacité pour contrôler l'adaptation du nouveau-né au nouvel environnement auquel il est exposé après la naissance. Cette méthode de mesure n'est pas invasive; son application clinique est simple et sans danger pour le nouveau-né.

Mots-clés: Adaptation néonatale, consommation d'oxygène $\left(\mathrm{V}_{2}\right)$, nouveau-né, surveillancé, température rectale (RT), thermorégulation. 


\section{References}

[1] Adamsons, K. JR, G. M. Gandy, L. S. James: The influence of thermal factors upon oxygen consumption of the newborn infant. J. Pediatr. 66 (1965) 495

[2] Blattels, C. M.: Shivering and nonshivering thermogenesis during hypoxia. Environ. Physiol. 2 (1972) 151

[3] BRÜCK, K., M. BRŨck, H. Lemtis: Die Temperaturregelung Neugeborener und Frühgeborener nach spontaner und pathologischer Geburt. Geburtshilfe Frauenheilkd. 20 (1960) 461

[4] BRÜCK, K.: Temperature regulation in the newborn infant. Biol. Neonate 3 (1961) 65

[5] BRÜCK, K.: Heat production and temperature regulation. In: Stave, U.: Perinatal Physiology. Plenum Publishing Corporation, New York - London 1978

[6] MiChEL, C. F., CH. SCHuBRING: Gerät zur kontinuierlichen Messung des Sauerstoffverbrauches bei Neugeborenen. Z. Geburtshilfe Perinatol. 177 (1973) 449

[7] Pribylova, H., K. Znamenácek: Some aspects of thermoregulatory reactions in newborn infants during the first hours of life. Biol. Neonate 6 (1964) 324
[8] SALING, E.: Die $\mathrm{O}_{2}$-Sparschaltung des fetalen Kreislaufes. Geburtshilfe Frauenheilkd. 26 (1966) 413

[9] SCHAefer, K. E., W. WünNENBERG: Threshold temperatures for shivering in acute and chronic hypercapnia. J. Appl. Physiol. 41 (1976) 67

[10] Schubring, CH., C. F. MrChEl: Kontinuierliche Messung des Sauerstoffverbrauches bei gesunden Neugeborenen in den ersten zwei Stunden nach der Geburt. Geburtshilfe Frauenheilkd. 34 (1974) 835

[11] Schubring, Ch., C. F. Michel, W. Höbel: Oxygen consumption, heart rate, respiratory rate and rectal temperature in healthy newborns during the first two hours after birth. J. Perinat. Med. 4 (1976) 72

Received January 7, 1985. Accepted March 5, 1985.

Priv.-Doz. Dr. med. Christian Schubring Abt. Geburtshilfe und Gynäkologie Ev. Krankenhaus Paul-Zipp-Straße 171 6300 Gießen, Fed. Rep. Germany 